\title{
Art and Money: \\ Constitutional Rights in the Private \\ Sphere?*
}

\author{
CHRISTOPH BEAT GRABER† and \\ GUNTHER TEUBNER
}

\begin{abstract}
The present debate on constitutional rights aims to protect the individual against the intrusive power of the state. Analysing the precarious relationship between art and money, the authors argue that constitutional rights need to be extended into the regimes of private governance. This requires four fundamental changes. (1) Constitutional rights can no longer be limited to the protection of individual actors. Instead, they need to be extended to guarantees of freedom of discourses. (2) The new experience of the twentieth century is that totalizing tendencies have their origin not only in politics, but also in other fields of action, especially in technology, science, and the economy. Thus, a discursive concept of constitutional rights should be directed against any social system with totalizing tendencies. (3) Instead of concentrating on centres of economic and social power, constitutional rights in the private sphere should focus on the specific communicative medium of the expansionist social system involved. (4) This excludes the direct analogy of a 'right' as a quasispatial exclusion zone. More significant guarantees of discursive autonomy could be found in a 'proceduralization' of constitutional rights.
\end{abstract}

Federico Fellini v Silvio Berlusconi-the grand old man of Italian cinema against the new media tycoon, Italy's former prime minister-was a cause célébre in the late 1980s. Fellini was furious. Canale 5, Berlusconi's aggressive commercial TV station, had mutilated his masterpiece Otto $e$ mezzo. Numerous commercial breaks had interrupted the flow of the film's artistic messages and distorted its integrity as a piece of art. Fellini claimed that his personal 'moral right' which was protected by the Italian constitution had been violated and asked the court to prohibit TV commercial breaks interruption of Otto e mezzo. ${ }^{1}$ Fellini's suit

- We would like to thank Anne Barron for helpful comments.

t Senior Research Fellow, Institute for European and International Economic Law, Univensity of Berne.

f Otto Kahn-Freund Professor of Comparative Law and Legal Theory, London School of Economics.

Under Ant 6bis of the Beme Convention on Copyright (1928 revision), in author shall have the right, inuer atia, to object to any distortion, mutilation or other modification of, or other derogatory action in relation to, his work, which would be prejudicial to his honour or reputation. For the treatment of moral rights in British law see the Copyright, Designs and Patents Act 1988, ch IV; G. Dworkin and R. D. Taylor, Blackstonet Guide to the Copynight, Daryns and Patents Act 1988, (London, 1990) ch 8; J. Ginsburg, 'Moral Rights in a Common Law System' (1990) 4 Ent LR 121. 
was only part of a broader campaign by famous Italian film makers like Franco Zeffirelli and Francesco Germi to protect the integrity of their films against commercial breaks. ${ }^{2}$ First the courts hesitated. But, the Serafino case in 1989, in which Germi succeeded in an action, signalled a decisive shift of direction. In contrast to regulations in other EU countries which in general allowed commercial breaks in films, even of those with artistic quality, and imposed only limits on the number, ${ }^{3}$ the Core di Appello di Roma invoked the human rights of the Italian constitution in order to protect artistic films from being deformed by commercial breaks. ${ }^{4}$ One may welcome this result as sound cultural policy, ${ }^{5}$ but why should the claim of the artist in this kind of case be regarded as raising a question of constitutional rights?

Art sponsorshhip is our second example in the triangle of art, money, and constitutional rights. At issue here is whether the relationship between art and money can be, or ought to be, treated as a matter of constitutional law, given that the latter has traditionally been regarded as regulating the activities of agencies of the State. Seen from this perspective, commercial sponsorship of the arts, though now widely seen as enabling rather than threatening artistic expression, raises similar questions to those considered in the Serafino case. In Great Britain, Germany, and Switzerland an exponential growth in business sponsorship has been observed. ${ }^{6}$ Business firms systematically finance artistic events (exhibitions, concerts, dance, or film festivals) in order to improve their corporate image. They keep the efficiency of business sponsorship activities constantly under review and make the continuation of these activities dependent on their success in marketing terms. Some critics argue that the expressive freedom of artists is thereby endangered and demand state supervision of arts funding; others welcome commercial sponsorship and demand that the state retreats from any subsidizing activities. ${ }^{7}$ The question we pose here, however, is whether such sponsorship can be seen as a constitutional issue, and if so, in what sense.

\footnotetext{
2 The court (ie Pretore di Roma) rejected Fellini's claim, see Dirito informasione e informanca, 1986, 160ff. For a discussion of the cases see Mario Fabbiani, 'L'introduction des spots publicitaires durant la projection televiste d'oeuvres cintmatographiques par rapport d la protection du droit moral de l'auteur' (1988) 137 Revue intemationale du drvit d'auteur, 45-57 (49-52); Christoph Beat Graber, Zwischen Geist und Geld. Interferenzen von Kunst und Wirsechafi aus mekticher Sicht (Baden-Baden, 1994) at 158-65; Eric Barendt, Broadcarting Law: A Comparative Study (Oxford, 1993) at 208-9.

3 The EU-Directive on Transfrontuer Television passed on 3 October 1989 (OJ L 298/23, 17 October 1989, OJ L 331/51, 16 November 1989) define onty the aims of regulation in the ficld of television and leaves it to the member States to transform them into the law of the land. Unsurprisingly the normative standards in the different EU Member States are quite diverse, see Barendt, $\mathrm{n} 2$ at 210.

4 Conte di Appello di Roma of 16 October 1989, $I$ diritto di autone, 1990, 98-107 (Germi's Serafino); see Taddeo Collowà, 'A proposito della intertuxione dei film in televisione a mezzo di measaggi pubblicitari' (1990) $h$ dritzo di astore, 199-228. According to Barendt, $\mathbf{n} 2$ at 209, it seems unlikely that an English court would adopt the rigorous approach of the Rome Appeal Court.

3 Ironically, the Italian people decided-volonté generale volonté de tous-in a referendum in June 1995, that the interruption of films, even those with artistic value, by commercial breaks should be allowed on television.

- On busuness sponsorahip of arts in the UK for 1972-83, see Council of Europe, Repon on Privaze Sponsorship of the Ars, Doc 5465, Strasbourg, 26 September 1985, 11. For a comparative anatysis, see Graber, n 2 at 21, 23, 66.

${ }^{7}$ See the discussion in Peter Roth, Kutwrsponsoring (Landsberg, 1989) 24f; Graber, n 2 at 24.
} 
The classical formulation of constitutional rights both in law and political philosophy would tend to answer this question in the negative. ${ }^{8}$ Constitutional rights, it is generally said, are human rights: they are rights of the individual against the intrusive power of the State. Yet in our two examples we are dealing with artistic expression and business organizations. Where is the individual that needs protection against the State? In the classical view the relation between art and money is simply not contemplated by constitutional rights.

We aim to challenge this view. The relation between freedom of art and the economy, it seems to us, is one of the key areas of constitutional rights. ${ }^{9}$ Indeed, its reformulation in terms of constitutional rights is one of the most pressing problems today, comparable to the problematic relation between freedom of science and the economy. An adequate understanding of the historical and contemporary role of constitutional rights in the 'private sphere' is blocked by the narrow view that these rights are constituted exclusively in the triad of individual-power-State. This narrow view is due to an unholy alliance between liberal political philosophy and the procedures of public law. Separation of State and society, the dichotomy between a public and a private realm, the reduction of social life to the actions of individuals, the view of the State as the organization of society, contractual theories of the State, society subsumed under the exclusive dichotomy State $\mathrm{v}$ individuals - these elements are responsible for an exclusively individualistic formulation of constitutional rights. ${ }^{10}$ They would not be so influential in constitutional law were they not reinforced by the procedures of public law. When individual citizens have the right to sue state agencies for the violation of constitutional rights, then this two-party relation of plaintiff and defendant constructs a social reality which is effectively governed by the dichotomy of individual $v$ State. Non-individual aspects of constitutional rights are subsumed under this dichotomy.

The heated debate about a Bill of Rights which is taking place in Britain also tends to concentrate on the individual-government relation. " For the role of constitutional rights in the private sphere the most advanced proposal is that the Bill of Rights should apply to 'any act or omission by or on behalf of any person (including the Crown) in the performance of any public function'. ${ }^{12}$ While this is a remarkable step beyond a merely government-oriented view of human rights

\footnotetext{
B Henkn, The Righes of Man Today (London, 1979); J. Donnelly, The Concept of Human Rights (London, 1985 ) at 6 . Against this 'standard assumption' $W$. N. Nelson, 'Human Rights and Human Obligations' (1981) 13 Nomos 281 has developed an institutional formulation of constitutional rights. In Europe, after the Second World War the German Constitutional Court approved step by step such an institutional formulation of constitutional rights. See Dieter Grimm, Die Zukunft der Veffassung (Frankfurt, 1991) at $221 \mathrm{ff}$. But in France and Germany there is a strong countermovement that defends the classical version. For France, see Philippe Braud, La notion de tibert pubtique en droit franfais (Paris, 1968) at 85, for Germany, Emst Forsthoff, Rechussaat im Wandd (2nd edn, Munich, 1976) ch III, V; Bernhard Schlink, 'Freiheit durch Eingriftsabwehr-Rekonstruktion der klassisctien Grundrechtsfunktion' (1984) Europdische Grundrechue Zeusechifi 457.

For a detailed defence of this, thesis, see Graber, $n 2$ at $173 \mathrm{ff}$.

${ }^{10}$ For a general critique of the narrow view, see Andrew Clapham, Human Righs in the Private Sphere (Oxford, 1993); Peter Saladin, Grundrechee tm Wandel (3rd edn, Bern, 1982) at 292ff, and Grimm, n 8 at $221 \mathrm{ff}$.

11 For an account of the current debate in Britain, see Clapham, n 10 at $67 \mathrm{ff} ; 298 \mathrm{ff}$.

12 A. Lester a al., $A$ British B Bll of Rights (London, 1990), Clause B and the comments, 19. Other proposals tend to stress the aspect of power or formal organization, see the analysis in Clapham, $n 10,330 \mathrm{ff}$.
} 
it still underestimates the reconstructive efforts reducing them to a change from 'governmental institution' to 'public function'. It is questionable whether the private/public distinction is a suitable criterion for the applicability of constitutional rights in the private sphere. Indeed, it may turn out to be counterproductive. It tends to nullify the advantages that a 'Diceyan' view on fundamental rights which judges public institutions and private actors by the same standards may have on human rights. ${ }^{13}$ The more fundamental reconstruction of constitutional rights which we suggest can be summarized in three points: (1) Constitutional rights do not only protect the freedom of individuals, rather, they extend to other non-individual expressions of freedom in society. (2) Constitutional rights are directed not only against state action, but also against the intrusions of other expansive social systems. (3) Constitutional rights do not exclusively deal with power relations, they curb any means of communication which tend to colonize other sectors of social life.

\section{2}

Sociological analysis is not much impressed by the rhetorics of pre-legal inalienable constitutional rights that spring from the natural endowment of human individuals and that the State has to recognize as such. Rather, sociology looks to underlying historical processes that make visible why constitutional rights emerge as a central feature of modern society. ${ }^{14}$ For pre-modern stratified societies, constitutional rights as a protected sphere of individual action are unthinkable. ${ }^{15}$ The individual is comprehensively embedded in social contexts, the legal formula is 'status' not 'right'; even the term 'ius' denotes a reciprocal contextual relationship and not a right in the modern sense. ${ }^{16}$

Rights as individual entitlements come about only with social differentiation. Their relevance is tied to the historical emergence of individual spheres of action which is typical for modern societies. ${ }^{17}$ Herein lies the key to understanding the historical role of constitutional rights. It is social differentiation that creates a variety of autonomous spheres of action, the autonomy of which is protected by complementary constitutional rights. The sphere of the self-realizing individual is only one among many spheres of autonomy in society which are guaranteed by constitutional rights as a social institution. Social differentiation and the emergence of constitutional rights are complementary historical processes. While in stratified societies, political action is closely intertwined with religious, legal,

\footnotetext{
13 ef Carol Harlow, "Public" and "Private" Law: Definition Wrthout Distinction' (1980) MLR 241; P. Cane, 'Public and Private Law: A Study of the Analysis and the Use of a Legal Concept' in J. Eekelaar and J. Bell (eds), Oxford Eseays in furisprudence (Third Series, 1987) at 57.

it See Grimm, n 8, 67ff.

15 See Nitlas Luhmonn, Grundwechte als Institution (Berlin, 1965) at 33f. On the various discontinuities of modern society see Anthony Giddens, The Consequences of Mademity (Stanford, 1990) at $4 \mathrm{ff}$.

${ }^{16}$ On the concept of 'ius' in a historical perspective see Michel Villey, Lefons d'histoire de la philosophie due droit (Pans, 1957) at 249fL

${ }^{17}$ For recent theorizing on social differentiation, see JOrgen Habermas, The Philosophical Discourse of Modernity (Boston, 1988); Niklas Luhmann, The Dhffentiation of Sociaty (New York, 1982) at 69-89.
} 
economic, and social meaning and inherently limited by this social context, modern politics and the State in its autonomy lose their inherent limitations and tend to politicize the rest of society. But here, other spheres of communication have gained an equal status of autonomy: ${ }^{18}$ religion, education, economy, science, law, health sector, mass media, and art. In the expansionist tendencies of the modern State, the historical process of social differentiation threatens to undermine itself. The self-destructive circle has the following stages: differentiation of politics-autonomy-loss of inherent limits-expansionist tendenciespoliticization of other sectors-risk of de-differentiation. Constitutional rights emerge as a social counterinstitution which breaks this vicious circle. ${ }^{19}$ They protect social differentiation against its self-destructive tendencies. They are not a creation of the law, but are pre-legal as a social institution, as a self-limitation of politics. Of course, the law positivizes, interprets, and stabilizes them. But this should not obscure the fact that constitutional rights are first and foremost social institutions which underlie the institution of law. This relation between the social and the legal explains why certain countries that have only a weak legal institutionalization of constitutional rights nevertheless have them institutionalized socially. ${ }^{20}$ And it explains why the legal imposition of constitutional rights has only a limited effect in those countries where social differentiation and its complementary institutions are not present as a social basis for the legal superstructure. ${ }^{21}$

In a sociological perspective we can see why the classical individualist interpretation of constitutional rights is too narrow and should be complemented (not replaced) by an institutional interpretation. ${ }^{22}$ The simple dichotomy of State $\mathrm{v}$ society does not consider the multiplicity of social discourses, the autonomy of which is defined by constitutional rights. The reduction of constitutional rights to individual spheres of action does not take into account that freedom in society is realized not only in the individual sphere but in different communicative spheres as well. ${ }^{23}$ How meaningful is it to protect individual freedom of opinion, if there are no constitutional guarantees for the communicative process, for the institution of a 'free press'? Is the freedom of academic teaching and research

\footnotetext{
18 See Niklas Luhmann, 'The Autopoiesis of Social Systems' in F. Geyer and J. van der Zouwen (eds), Saciocybernetic Paradoxes: Observation, Control and Evolution of Salf-Stacting Syrzems (London, 1986) at $172-92$.

19 See Christoph Beat Graber, 'Pecunia non olet?' (1991) 110 Zeitschrift fir Schweiverieches Recht 237-63, 253ff.

20 In the absence of a written constitution and judicial review of legislation, everything depends on the viablity of 'conventions' and the social conditions of their norm production. For Great Britain, see Vernon Bogdanor, Politus and the Constution (Aldershot, 1996); Denis Galligan, 'Myth and Reality in the English Constitution' (1997) Canto di studi e ricerthe di dirito comparato no 25; Eric Barendt, 'Is There a United Kingdom Constitution?' (1997) 17 OJLS 36144.

21 The useful distinction between 'façade constitution' and 'garantiste constitutions' has been introduced by Giovanni Sartori, 'Constitutionalism: A Preliminary Discussion' (1962) 56 American Political Saience Roviow 853, 860.

22 A similar view is proposed by Joseph Raz, The Monality of Freedom (Oxford, 1986) at 253-4. Constitutional rights do not only protect individual interests, but also collective goods, like the freedom of the press, free political speech and others. An institutional perspective would, however, not only see individual basic rights as instruments for the protection of collective goods, but define social institutions themselves as the subject of constitutional rights, and translate this into procedural requirements.

23 This point is elaborated by Helmut Willke, Stand und Kritik da newern Grundrechestheorie (Berlin, 1975).
} 
exhausted by the individual freedom of the university scholar? Or is the communicative process of research and publication itself a matter of constitutional protection? Is it sufficient to grant political liberty to the citizens or is it the process of collective will formation that needs to be protected against intrusions from the State? ? $^{24}$

This is not an anti-individualist view which denigrates constitutional protection of individual spheres of action. On the contrary, social differentiation has been accompanied by a hitherto unknown autonomization of the individual. Individual dignity and individual freedom are vulnerable against the intrusion of politics, and as the experiences of totalitarian regimes have shown, are in desperate need of the protection afforded by constitutional rights. But this should not lead to view, in each and every constitutional right, a simple concretization of individual freedom as the dominant view in constitutional law has it. Constitutional rights can be seen as polyvalent, protecting both individual spheres of action and social spheres of action against the expansionist tendencies of the State. In particular, we can distinguish: (1) those constitutional rights that are predominantly oriented towards protecting the sphere of action of the individual (right to individual liberty and right to personal dignity); (2) those that protect simultaneously individual and social spheres of action (freedom of opinion, of art, of education, of research); and (3) those that protect predominantly an autonomous sphere of social action (property, family, political constitutional rights).$^{25}$

This is not a collectivist view which identifies collectives and social institutions as originally entitled to constitutional rights and sees the individual as a mere instrumental functionary of those collectives. ${ }^{26}$ On the contrary, the two fundamental constitutional rights, the right to individual liberty and the right to personal dignity are the main guarantees for the individual sphere of action outwith the large collectives, directed particularly against large scale organizations. The point is that apart from individual spheres of action there are spheres of social autonomy that need constitutional rights protection against the colonizing tendencies of state politics and that cannot be reduced to mere annexes or derivations of individual autonomy. It is the decentering of the individual, not its withering away which is asked for in the field of constitutional rights. ${ }^{27}$

However, one has to reckon with conflicts between individual and social autonomy, situations in which individual autonomy endangers social autonomy: the journalist violating the freedom of the press; the scholar violating freedom of research; the citizen violating freedom of the political process. The law has to deal with these conflicts. In these cases constitutional rights may need to be

\footnotetext{
24 See Karl-Heinz Ladeur, Postmodame Rechssheorie (Berlin 1992) at 176ff.

${ }^{23}$ See Luhmann, n 15 at chs 5-7; Willike, n 23 at 164-77. Clapham, 1993, n 10 at 145-9, comes close to this typology when he distinguishes between human rights that are related to human dignity and others that are related to democracy.

${ }_{26}$ For this debate, see Meir Dan-Cohen, Rights, Persons, and Organizations (Berkeley, 1986) and 'Between Selves and Collectivities' (1994) 61 Unioursity of Chicago Lato Revieto 1213-43.

${ }^{27}$ See Gunther Teubner, 'How the Law Thinks: Toward a Constructivist Epistemology of Law'(1989) 23 Law and Sacinty Reviow 727-57; Graber, n 2 at 175-8.
} 
protected against their individual bearer, as absurd and dangerous as this may sound to advocates of a strictly individualist approach to constitutional rights.

\section{3}

Let us return to Otto e mezzo and the film makers' protest against the violation of their constitutional rights. In some of these cases the film makers had given their approval to any sort of diffusion of their films. The contracts contained such broad formulations that their approval would appear to cover commercial breaks. ${ }^{28}$ And indeed, the Italian courts who were willing to protect films against commercial breaks in general, made the exception that there would be no protection of the constitutional right if the film maker had given approval to the mutilation in question..$^{29}$ According to the court the 'author has the right to sue against any act that damages his work in terms of deformation, mutilation or any substantive modification. This includes the protection of the author also against the use of his work for commercial advertisement in a way that offends the dignity of the author'. But this protection ends if the author has given his prior consent. ${ }^{30}$

Indeed, such a distinction is in line with an individualist interpretation of the constitutionally guaranteed freedom of art. It is in conflict, however, with its institutional interpretation which would demand the protection of art even if the artist has agreed to the damaging interference. Of course, freedom of art has its individual dimension. It protects the free expression of the artist's personality and-in a broader interpretation-the social and economic conditions of the artist's activities. But at the same time freedom of art is a fundamental right which is concerned with the discourse of art itself. Art in this sense is a selfreproductive communicative process that includes all kinds of communicative observations of artistic distinctions, from the creation of artistic artefacts to their enjoyment by the public and their critique. ${ }^{31}$ At the centre of this process is not the artist, neither as a god-like genius, nor in his right to personal expression, nor in his private property of the piece of art, rather it is the discourse between artist and public which is attracted by the artistic artefact. ${ }^{32}$ Freedom of art is not primarily related to the unfolding of the artist's idiosyncratic personality, but to the social construction of alternative realities, to the discovery of counterworlds to everyday communication, to the creation of an imaginary world through artistic artefacts. They protect the conditions of possibility of an autonomous

\footnotetext{
20 In practice it happens very often that an author agrees by contract to commercial breaks. Chardin asks if the author by doing so does not commit 'moral sucide'. See V. Chardin, 'Le droit moral du réalisateur sur l'oeuvre gudiovisuelle achevee' (1989) 21 Cahiers du drout d'avteur.

20 See Collova, in 4 at 199-228 (213).

30 See Corre di Appello di Roma, 16 October 1989, Il dirito di autore 1990, 99, 105.

31 Niklas Luhmann, Die Kurst der Gesellschafi (Frankfurt, 1995) at ch 1.

32 This refers to the topic of decentring of the author which has been dealt with by several strands of aesthetic theorizing, Theodor W. Adomo, Aesthetiche Theone (9th edn, Frankfurt, 1989, Engl trans Aestherse Theory, London : Athlone, 1997); Michel Foucault, 'Qu'est-ce qu'un auteur?' in Bulleain de la Sacuéte framsaise do la Philosophie (Paris, 1969); M. Baxandall, Pattems of Intention (New Haven, 1985).
} 
discourse of art. ${ }^{33}$ In extreme cases, this might lead to a protection of the artist against himself, to a protection of the play of distinctions around the artefact against its mutilation, if necessary against the will of the artist or his heirs. ${ }^{34}$ In our case Otto e mezzo, Fellini's constitutional right is non-renunciable, nondisposable. The court protects freedom of art in its non-individual institutional aspects as a non-distorted communication process, even if the author has given his consent.

This view opens unconventional approaches to protect the self-reproduction of art against modern dangers. These dangers lie not only in the old repressive power of the State or in more recent forms of political corruption of art. They lie especially in forms of exclusive privatization of art. ${ }^{33}$ If art needs constitutional protection as a self-reproductive discourse centred around artistic artefacts, then a right of public access to private art collections should not be excluded from the outset. In this spirit the law of intellectual property would have to be redirected from a person-centred view that protects the dignity, personality, and creativity of the author, to a discourse-related view that instead of the author's personality protects artistic communication by preserving the artistic patrimonium of society. ${ }^{36}$

This brings us to the second question: Against whom are constitutional rights directed? The classical answer is unequivocal: against the power of the State. It denies any protection against 'private' infringements of basic rights, particularly against economic organizations:

Although most liberal states protect basic rights against abuse of power by agencies of the State, their laws generally fall short of adequate protection of civil liberties against the economic powers by employers. ${ }^{37}$

This failure of labour law to protect constitutional rights extends to most other spheres of 'private' life. It is true, the historical role of basic rights has been to protect the precarious results of social differentiation against their politicization. ${ }^{38}$ The historical outcome was a self-limitation of politics. In long-term political struggles the State was compelled via constitutional rights to respect spheres of

33 On the autonomy and closure of art, see Luhmann, n 31 at ch 4.

34 Graber, n 2 at 183.

35 Theodor W. Adomo, Dissonanzen. Einleinung in die Musiksoziologie, Gesammathe Sehrifien Vol. 14 (2nd edn, Franlfurt, 1980) at 14-51, Engl trans Intraduction to the Socidogy of Muric, New Yort, 1976); Graber, $n 2$ at ch. 3.

36 See the discussion about an objectified protection of the work of art as such in Germany (Wertuchutrrachs)


denaschen Utheberrech (Munich, 1968) at 90-116; Henri Desbois, Le droit d'autew en France (2nd edn Paris, 1966) at 483-507. This orientation toward the artefact, however, does not go far enough, and should be changed into an orientation toward artistic communication itself. Arguments for such a reorientation of the law are developed by Anne Barron, 'Copyright, Culture and Creativity' (manuscript, LSE, London, 1997 ).

37 Hugh Collins, Furtice in Dimiscal (Oxford, 1992) at 184-215.

10 See Dieter Grimm, Reeht wrd Staat in der bojoutichen Gesellschafi (Frankfurt, 1987) at 192ff. 
individual and social autonomy. Private spheres of individual life as well as society-wide discourses-religion, science, art, law, economy-were protected against the intrusion of political power. And it is no wonder that the totalitarian regimes of the twentieth century dismissed constitutional rights as outdated liberal institutions that hindered the political mobilization of all sectors of society. Consequently, the re-institutionalization of constitutional rights in 1945 and 1989 on the Continent was a necessary condition not only for individual liberties but for a renewed autonomy of a variety of social discourses against their politicization. To characterize the anti-totalitarian changes in Europe as a return to liberal capitalism is therefore too narrow a view of these developments, which combine a high degree of social differentiation with an institutionalized guarantee of the autonomy of social discourses.

There is no room, however, for complacency about constitutional rights. If one looks at the risks for social differentiation, the 'end of history' is not in sight. It is true that constitutional rights were directed against the risks of dedifferentiation stemming from the expansionist repressive State. But this is a historical contingency depending on the expansive potential of a social system in a given society at a given time. Silicon Valley, we submit, carries potentially as many risks for the freedom of science, education, and research as Lyssenkow's socialist biology. In a sense, its dangers for cultural autonomy may be even greater. Lyssenkow's political biology transformed science straightforwardly into politics, turned a scientific theory into a political ideology, and by this transformation destroyed its inner dynamic. Silicon Valley, the symbol for a close symbiosis between economic profit and scientific truth, seems more dangerous because it preserves the scientific machinery in order to exploit it for economic purposes. There is a more subtle danger for the loss of academic autonomy and scholarly integrity if the direction of research is predominantly determined by conceptions of economic and social utility generated elsewhere. Is there something like a 'horizontal effect' of constitutional rights that would protect the fragile structures of social differentiation against colonizing tendencies of social systems other than politics?

The contemporary debate on constitutional rights has developed three diverse doctrines of their horizontal effect in the 'private' sphere which we find promising but wanting. ${ }^{39}$ One doctrine resorts to the minimal position of an 'indirect' horizontal effect of constitutional rights. ${ }^{40}$ In private law, constitutional rights cannot be applied directly since they are designed for the individual-state relation. However, they have an indirect effect in private law; their inherent values can be realized in the interpretation of general clauses like 'good faith', 'public

\footnotetext{
39 For an extenswon of civil liberties into British contract and labour law, Collins, $n 37$ at 184-215. For a recent comparative analysis of horizontal effect of constitutional rights which refers mainly to the Strasbourg Conventon and Britain but which discusses also the US and Canada, Clapham, n 10. In the continental legal literature the discussion on the horizontal effect was initiated in the 1950 . An overview of the development of the doctrine in Saladin, n 10 at $307 \mathrm{ff}$.

${ }^{40}$ See Peter Saladin, 'Grundrechte und Privatrechtwordnung' (1988) 22 Schweizerische furisten-Zatung 373-84, $382 \mathrm{f}$.
} 
policy', and standards of a 'reasonable person'. Arguably, this doctrine makes the point that constitutional rights cannot be transferred from the traditional political context to the economic context without a thorough re-formulation. But this doctrine does not develop criteria as to under what circumstances constitutional rights can be invoked against economic action.

Another is the 'state action' doctrine which expands constitutional rights beyond the narrow field of governmental action and applies them to all types of economic and social action, however under the condition that an element of state action can be identified. ${ }^{41}$ Under the conditions of a mixed society with comprehensive state intervention this leads to a quite dramatic expansion of constitutional rights, for example against racial discrimination by exclusion of membership in a private club if only a state-granted liquor licence exists. However, the theoretical criterion is wrongly chosen-state action instead of effective infringement of individual or social autonomy whatever its source.

A third doctrine stresses 'economic and social power' that threatens individual autonomy ${ }^{42}$ Wherever in society organized centres of power do exist, individuals should enjoy the protection of constitutional rights. Again, we would criticize as too narrow an orientation which this time does not try to identify indirect state action in private contexts, but looks for structural analogies to the power of the State and finds them in institutions of 'private government'. It is an obsession with phenomena of power that tends to overlook other media of communication as threats to individual and social autonomy.

Instead, it is the specific communicative medium of an expansive social system against which individual and social autonomy needs to be protected, in analogy to the protection against the power medium of the State. Economy and technology are the obvious new candidates. We have already mentioned the Silicon Valley syndrome as a fundamental threat to academic freedom. And one could even argue that political discourse itself needs fundamental rights to be protected against the colonizing tendencies of the expansive economy ${ }^{43}$ An ironic reversal of fronts! Constitutional rights designed to protect economic freedom against the repressive State might now be used to protect political freedom against economic influences. ${ }^{44}$ No doubt that this is a constitutional rights problem of the first order. Not only does politics need to respect the autonomy of the economic generalization principle, but the reverse is equally true. 'The economy needs to respect the genuinely political processes of power accumulation if it is not to sacrifice its long-term interests to short-term advantages. The economy needs to respect the political principle of interest generalization and must not give in to the temptation of its decentralized decision structure: namely to buy

\footnotetext{
11 Particularty in the United States, for a detailed analyxis see L. Alexander and P. Porton, Whom Dows the Consrinurion Demand (New York, 1988).

${ }^{42}$ See Clapham, n 10 at 330ff, on the British discussion of the criterion of social and economic power. The continental situation is discussed by Peter Saladin, Verantwontung als Staatsprinstp (Bern, 1984) at $168 \mathrm{ff}$.

${ }^{43}$ One could think of constitutional limits against the introduction of New Public Management methods into those fields of public administration where the logic of the market is inadequate.

${ }^{14}$ See Helmut Willke, Ironie des Staates (Frankfurt, 1992) at 335f.
} 
specific advantages via special deals. The economy needs to address politics with its interest in such a way that the State can take over political responsibility for its decisions. ${ }^{45}$ Recent political scandals in Germany and Italy concerning the financing of political parties by powerful economic groups (Flick and Enimont) are cases in point. Certain lobbying practices point into a similar direction.

What about art and money? There is a long-standing critique of the fetishization of art which makes the capitalist economy responsible for tendencies of reification of culture ${ }^{46}$ By the commodification of art, the effects are directed toward the exchange value of the art object. Enjoyment becomes a matter of sheer popularity of art. The autonomy of art is lost.

Insofar as art responds to socially existing needs, it has become to a large degree a profit-oriented enterprise which goes on and on as long as it is profitable, but it veils behind its perfection that it has died long time ago. ${ }^{47}$

We think this critique reflects adequately the endangerment of the autonomy of art through the colonizing tendencies of the economy. However, we are not sure to what extent this realization should provoke such deep pessimism as to the inevitability of art's loss of autonomy. Historically, economic prosperity has tended to coincide with a blossoming of the arts, and after 200 years of capitalism, art is still thriving in a state of lively imperfection. It seems to us that it is not the interdependence as such of art and money that creates the threat to the autonomy of art, but the concrete ways in which these interdependences are institutionalized. The question is whether contemporary society is in a position to develop social institutions that counteract a too direct dependency of art from economic action. The distinction between code and programme might be fruitful here, as well as the distinction between loose and tight coupling. ${ }^{48}$ Whereas the code of art is the expression of the autonomy of the discourse of art itself, aesthetic programmes which are historically contingent decide on the conditions under which the code operates. Translated into our language, Adorno's critique aims at a situation in which the code of art becomes replaced by the code of the economy. We would distinguish this from the more productive constellation in which the code of art remains intact while the programmes of art communication are influenced by the economy and other subsystems in society. And then everything depends on a development in which the relation between art and money evolves from tight to loose coupling. Of course, law plays a rather limited role in such social structures supporting cultural autonomy. As in the case of

\footnotetext{
45 Luhmann, n 15 at 115.

40 See Walter Benjamin, Das Kunstroerk in Zeivalter siner technischen Repraduszerbarkeil (Frankfurt, 1977) at 16; Adorno, $\mathrm{n} 32$ at 25.

${ }_{47}$ Adorno, n 32 at 34.

45 On code and programs of art, see Luhmann, $n 31$ at $301 \mathrm{ff}, 328 \mathrm{ff}$.
} 
the expansive State, it is the social institution of constitutional rights that protects social autonomy, and law's role is limited to stabilizing these rights and shaping them to a certain degree.

There seem to be two ways that the law can react to infringements of artistic autonomy through non-political mechanisms. One is the direct analogy to constitutional rights in relation to the State. The other is a legal arrangement that is not moulded in the legal form of a 'right', rather an equivalent in effect but in different legal forms. Let us go back to our two examples to illustrate these two ways.

In the Serafino case, the direct analogy has been tried. ${ }^{49}$ The moral right of the author has been re-interpreted as a constitutional right which protects the integrity of artistic communication against infringements not by the State, but by an economic enterprise. The social situation that art's autonomy is endangered by expansionist tendencies of economic transactions, is translated into the legal procedure of an individual rights claim against an economic organization. This works satisfactorily as long as the economic interference with art is structurally similar to a political interference which can be blocked by granting subjective rights.

Economic infringements, however, are often more subtle than a direct interference into a sphere of autonomy. Business sponsoring is a case in point where the construction of individual rights against economic interference would be useless. Here, a constitutional duty of the State to guarantee a multiplicity of financial sources for art seems to be a more productive device which could have effects on the autonomy of art equivalent to the rights construction. ${ }^{50}$ The autonomy of art seems to be better protected if artistic communication is financed by a plurality of sources and a monopolistic dependency of art on one source of financing is avoided. The consequence is that government should not retreat from interventionist support of cultural life and content itself with the replacement of state sponsorship by business sponsorship. Rather, it should attempt to influence the interdependencies of art and money in two ways. First, the State should use its financial resources to influence business sponsorship so that it resorts to more indirect, more abstract forms of sponsorship which leave more space for the autonomy of art. Tax law, matching techniques ${ }^{51}$ and the creation of art foundations seem to be the institutional lever which might be used to impose a 'code of business sponsoring' on corporate actors. ${ }^{52}$ They would systematically favour those sponsorship contracts that actually respect artistic autonomy. Second, the other institutional device would be a legal principle of financial pluralism in matters of art. The State would have to guarantee a

\footnotetext{
49 See Cone di Appello di Roma, 16 October 1989, Il dirito di auton 1990, 98-107.

so See on this proposal Graber, $n 2$ at 227-35.

51 Matching techniques are used, eg, by the British Arts Council or by the US National Endowment for the Arts. See F. F. Ridley, 'Traditon, Change, and Crisis in Great Britain', in Milton C. Cummings Jr and Richard S. Katz (eds) The Paron State at 225-53; Kevin V. Mulcahy Jr, 'Government and the Arts in the United States', ibid, at 311-32.

${ }^{52}$ See eg Association for Business Sponsorship of the Arts, The Sponsor $\$$ Gride, London, 1987.
} 
plurality of independent financial sources that would be an external condition for artistic autonomy and plurality. A kind of subsidiarity principle would be governing: a reliance on a multiplicity of private, local, communal, and regional financial sources which would be guaranteed by the State. Of course, such protective measures can only accompany constitutional rights which themselves need to be firmly rooted in social and cultural practices. 